IA WPE NOE LIWEAMOAE WATIONAL LABOAMTORY

High-Performance Laser Peening for Effective Mitigation of Stress Corrosion Cracking

Dr. L. hackel, Dr. H.-L. Chen, Dr. F. Wong, Professor M. Hill

October 2, 2002 
This document was prepared as an account of work sponsored by an agency of the United States Government. Neither the United States Government nor the University of California nor any of their employees, makes any warranty, express or implied, or assumes any legal liability or responsibility for the accuracy, completeness, or usefulness of any information, apparatus, product, or process disclosed, or represents that its use would not infringe privately owned rights. Reference herein to any specific commercial product, process, or service by trade name, trademark, manufacturer, or otherwise, does not necessarily constitute or imply its endorsement, recommendation, or favoring by the United States Government or the University of California. The views and opinions of authors expressed herein do not necessarily state or reflect those of the United States Government or the University of California, and shall not be used for advertising or product endorsement purposes.

This work was performed under the auspices of the U.S. Department of Energy by University of California, Lawrence Livermore National Laboratory under Contract W-7405-Eng-48. 


\title{
High-Performance Laser Peening for Effective Mitigation of Stress Corrosion Cracking
}

\author{
Dr. Lloyd A. Hackel, Dr. Hao-Lin Chen and Dr. Frank Wong \\ Laser Science and Technology Program \\ Lawrence Livermore National Laboratory \\ Livermore, California 94550 \\ Email hackel1@1lnl.gov \\ $\&$ \\ Professor Michael Hill \\ Mechanical and Aeronautical Engineering Department, \\ University of California \\ Davis, CA 95616 USA
}

\begin{abstract}
Stress corrosion cracking (SCC) in the Yucca Mountain waste package closure welds is believed to be the greatest threat to long-term containment. Use of stress mitigation to eliminate tensile stresses resulting from welding can prevent SCC. A laser technology with sufficient average power to achieve high throughput has been developed and commercially deployed with high peak power and sufficiently high average power to be an effective laser peening system. An appropriately applied version of this process could be applied to eliminate SCC in the waste package closure welds.
\end{abstract}

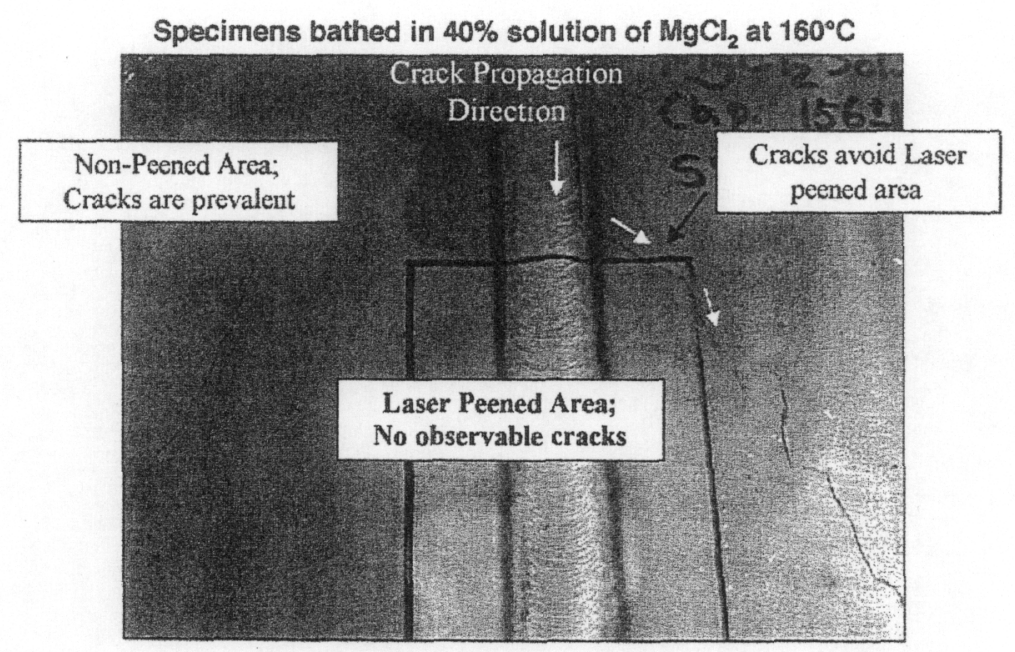

Laser Peening has been mitigating tensile stress residual stress at welds. 


\title{
High Performance Laser Peening for Effective Mitigation of Stress Corrosion Cracking
}

\author{
Lloyd A. Hackel, Hao-Lin Chen and Frank Wong \\ Lawrence Livermore National Laboratory, Livermore, CA 94550
}

Michael Hill

Mechanical and Aeronautical Engineering Department, University of California, Davis, CA 95616

Stress corrosion cracking (SCC) in the Yucca Mountain waste package closure weld is believed to be the greatest threat to containment. The three coexistent conditions bring about SCC are tensile stress, a corrosive environment, and susceptible metallurgy. Use of stress mitigation to eliminate tensile stresses resulting from welding can thereby prevent SCC. Laser peening offers a highly effective and easy-to-apply approach to introduce the desired compressive stress in the welded region and thus eliminate SCC as a serious problem. To increase the yield of successfully packaged canisters, we also proposed to use high-energy laser beams to selectively anneal and remove residual tensile stress not completely neutralized by the induction annealing process. The laser technologies required for both peening and annealing processes are mature and can be readily deployed. Successful implementation of the laser processes will enable YMP to produce higher-integrity closures, shorten production cycles, and reduce the costs of production and operation.

The basics of the laser peening process are described in Figure 1. A high-intensity laser beam with peak power in the range of $1 \mathrm{GW}$ is imaged to a spot size of about $1 \mathrm{~cm}^{2}$ and illuminates the metal substrate to be peened. The energy density of the laser is typically in the range of 100 joules per $\mathrm{cm}^{2}$ and the duration of the pulse is 20 to 30 nanoseconds (ns). The surface of the substrate is typically covered with an insulation/absorption layer, although in the Yucca Mountain application where surface finish is not a critical issue, 
the welded surface to be peened can act as the absorption layer. On top of the absorption layer is another layer that is transparent to the laser light and acts as a tamper, that is, as a confinement "cover" for the pressure that will build. When the laser beam illuminates

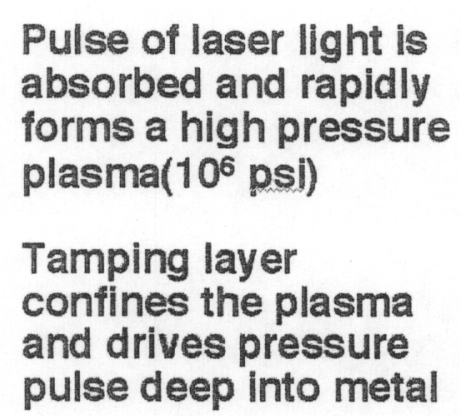

Pulse of laser light is absorbed and rapidly forms a high pressure Tamping layer confines the plasma pulse deep into metal

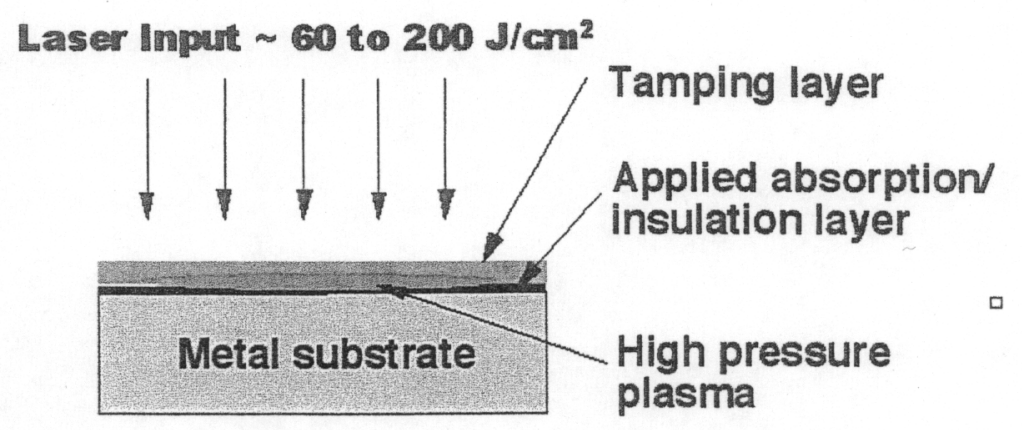

plasma

Compressive stress induced by laser peening can improve the fatigue strength of parts and resistance to stress corrosion cracking

Figure 1. Laser peening can be used to introduce compressive stress in welds.

the surface, it is absorbed and rapidly forms a high-intensity plasma. The plasma is confined by the tamping layer and builds to a pressure of roughly a million pounds per square inch. Although the tamping layer is only a 1-mm-thick layer of liquid, during the very short 20-ns duration of the laser pulse, its inertia keeps it from moving more than a few microns and thus it very effectively confines the pressure. This high pressure results in a shock wave that travels down into the metal, straining the material. Since the laser intensity is tailored to create a shock that is above the yield strength of the metal, a permanent residual compressive stress is induced. Thus the process can very effectively convert tensile stresses in the metal to strong and relatively deep compressive stresses.

The concept of laser peening has been around for 30 years, but only recently from development work at LLNL, has a laser technology been available with high peak power and sufficiently high average power to be an effective laser peening tool. This laser technology and an associated laser peening process are enabling greater throughput rates by a factor of 25 . This technology has proven to be so robust that it was rapidly transferred to a commercial process to fix a severe cracking problem that arose in a high- 
thrust jet engines fused on commercial aircraft. The photo below (Figure 2) shows the consequences of a fan blade fatigue failure that occurred in the fan section of a Boeing 777 during an aborted takeoff. Fatigue cracking was the source of the blade failure.
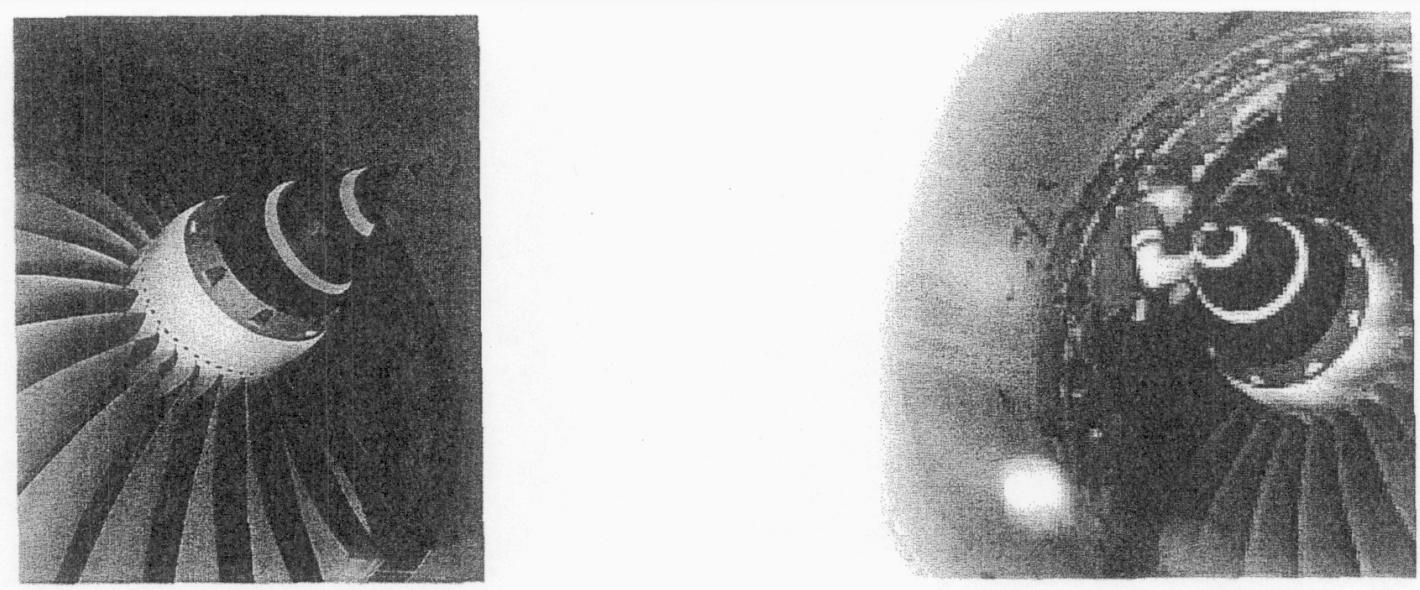

Figure 2. (At left) Jet engine capable of $98,000 \mathrm{lbs}$ thrust with complete fan section composed of 26 blades made of titanium 6-4. (At right) Consequence of fatigue failure cracking of fan blade dovetail. Introduction of commercial laser peening in May 2002 has solved this cracking problem.

Laser peening proved to be the key solution to applying compressive stress and is now significantly extending the lifetimes of blades. Full engine tests verified that blade failure after 500 simulated flights could be successfully delayed to 10,000 flights with laser peening. With application of this laser peening technology to the fan blades, crack propagation has been virtually eliminated. In commercial passenger service, the disassembly and inspection intervals on the jet engines have been safely extended from 100 flights to now a year-long 1200 flights. Advanced laser peening technology solved this metal cracking problem. An appropriately applied version of this process could eliminate SCC as a problem in the waste package closure welds.

Figure 3 shows the deep level of residual stress induced in 4340 steel (RC 50) after just two applications of laser peening. As can be seen, the induced residual stress extrapolates to be compressive to a depth of greater than 10 mills, that is several 
millimeters. Additional applications of peening are shown to drive this stress even deeper.

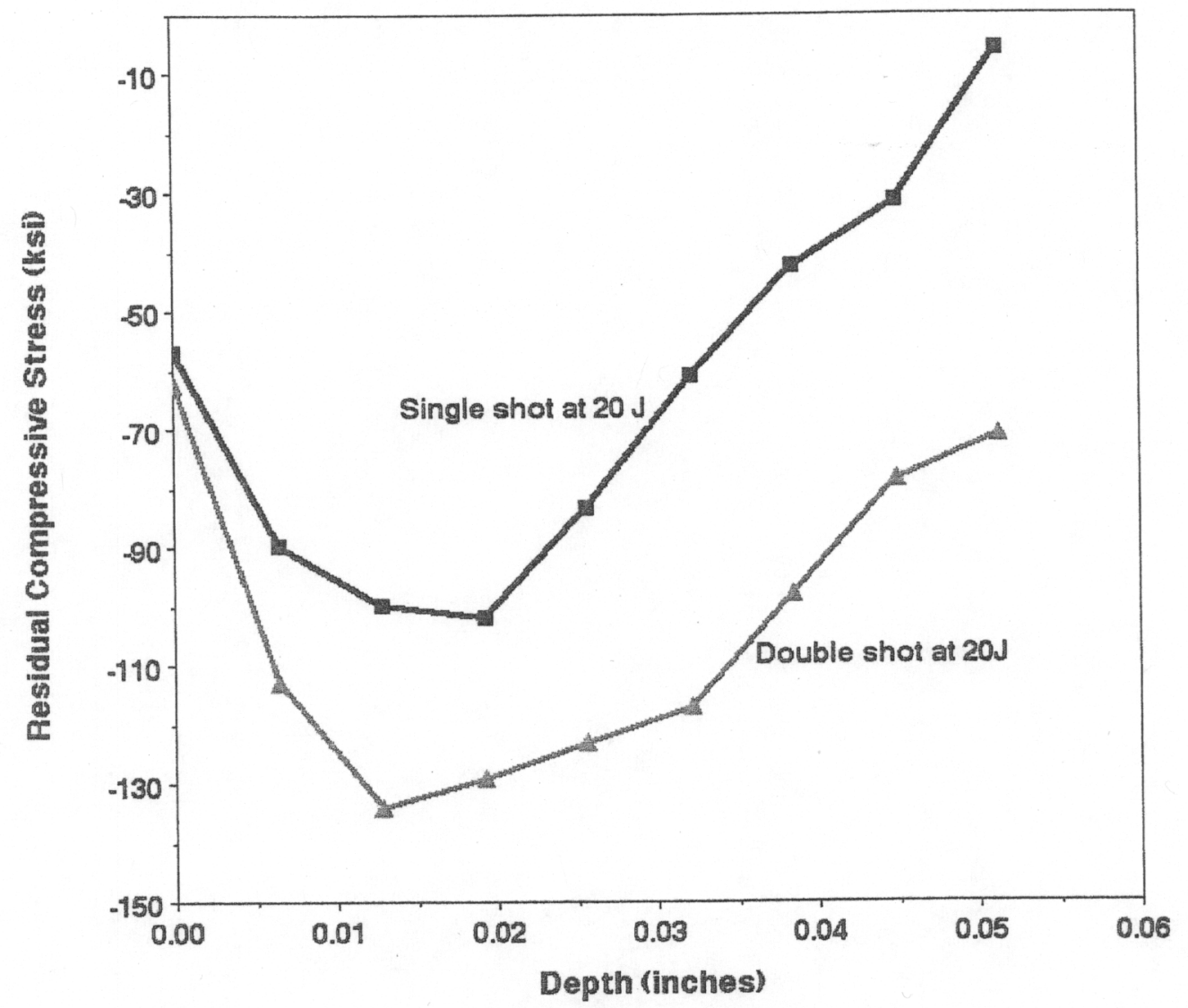

Figure 3. Residual stress induced in 4340 (RC 50) steel extends deeper with each application of laser peening.

Figure 4 shows a simple but graphic example of the benefits of laser peening on eliminating SCC. In this example, laser-peened and unpeened C-rings of 304 stainless steel are exposed to a solution of $40 \% \mathrm{MgCl}_{2}$ at $160^{\circ} \mathrm{C}$. After only two hours of exposure, the unpeened rings have all failed, BUT after 150 hours of exposure, the laserpeened specimens show no signs of cracking. 


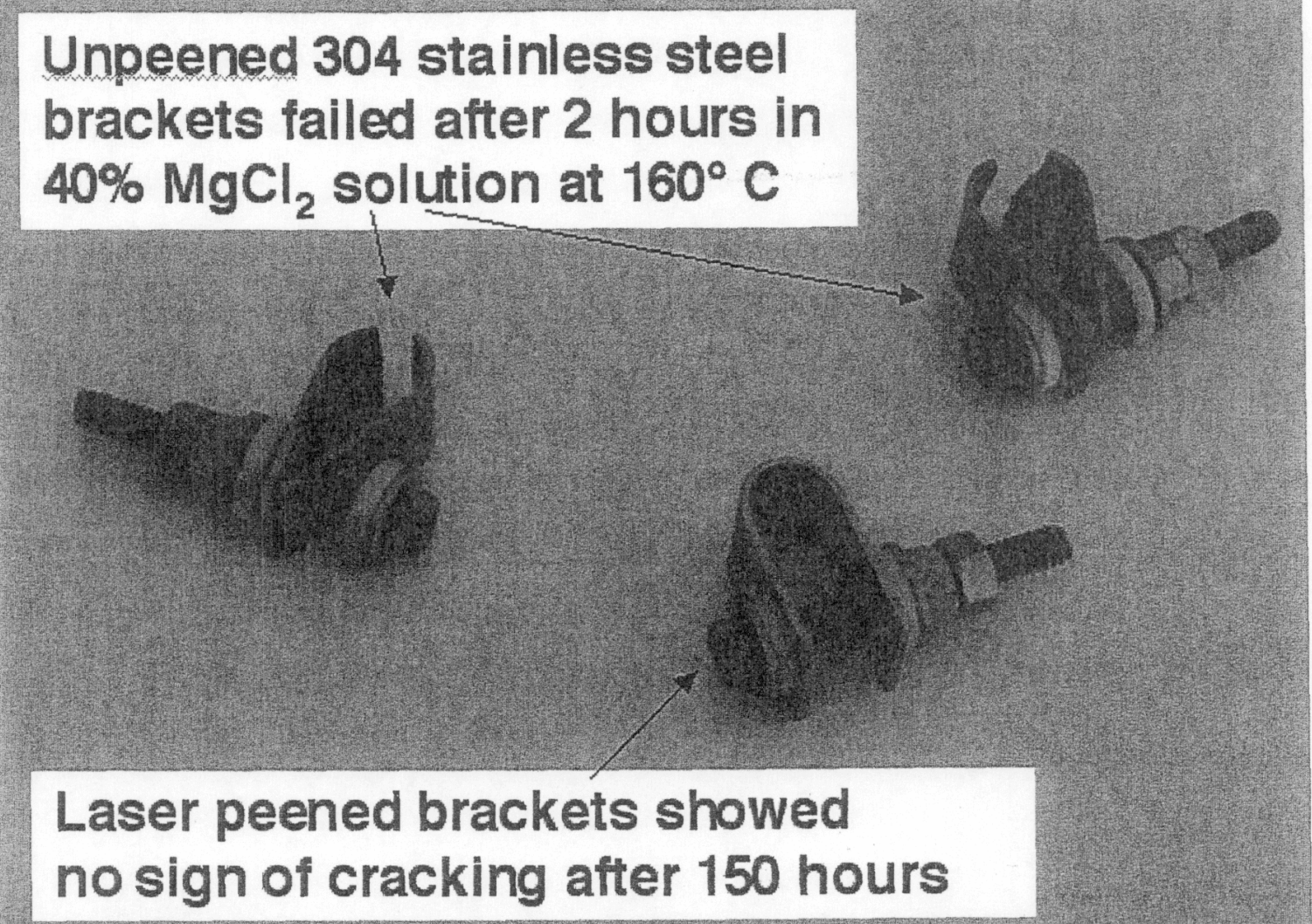

Figure 4. A simple C-ring test graphically shows how laser peening can significantly extend the lifetime of components against stress corrosion cracking.

In yet another example of mitigation of SCC, Figure 5 shows the results in a 1-inch-thick plate of welded 316 stainless steel after similar exposure to corrosive $\mathrm{MgCl}_{2}$. In this example, a crack along the weld (top of photo) propagates along the unpeened region but abruptly turns away as it hits the laser peened region. Not shown but equally significant, the crack abruptly stops in the region below when it hits a laser-peened region extending fully across the plate. 


\section{SCC in 1 inch thick welded 316 stainless avoids laser peened area}

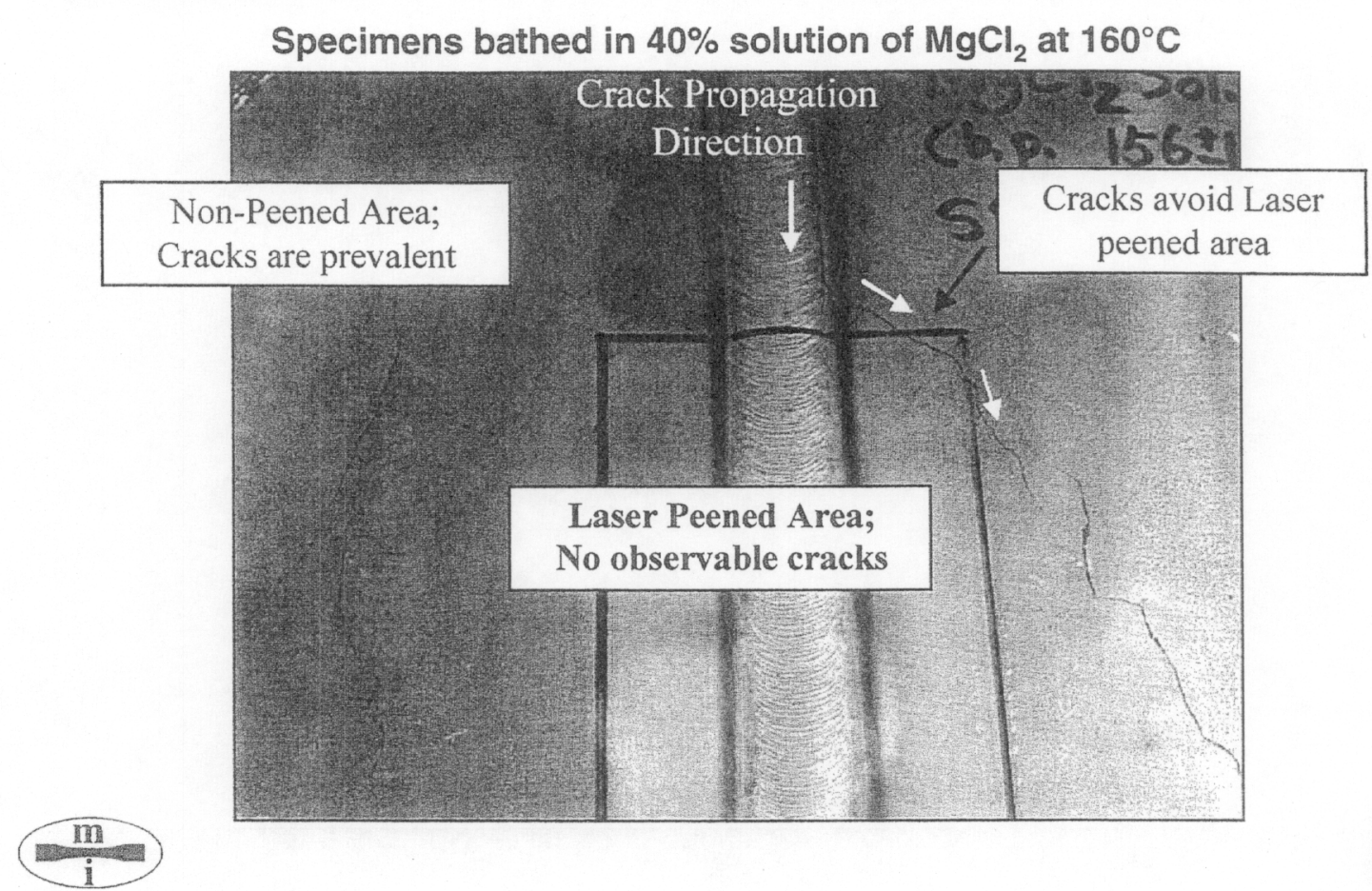

Figure 5.

These examples illustrate the potential of laser peening to eliminate stress corrosion cracking. The laser peening process is being convincingly used in the aerospace industry under a demanding industrial process. With appropriate modification of this process to provide even deeper levels of residual stress and to create a setup for use in a hot cell environment, laser peening could eliminate $\mathrm{SCC}$ as a serious problem for the Yucca Mountain Project. 


\section{Proposed Work}

The overall project is divided into two phases. Each of the two phases will be considered separately with specific budget and deliverables.

The First Phase will involve a comprehensive study of the laser peening technology to generate compressive stress at great depth in Alloy 22 welds. It consists of three essential tasks. Particular emphasis will be placed on achieving compressive stress at deeper depths $(>5 \mathrm{~mm})$ than has currently been demonstrated. We will develop and test optical transport and processing tools for hot cell operation. We will complete conceptual design of production-ready laser peening machine for application in YMP repository.

\section{Task 1: Optimization of laser peening process parameters to achieve compressive residual stress at deep layers in Alloy 22}

The laser peening process has been shown to transform the tensile stress in welded sections of Alloy 22 to compressive stress to a depth of about 1 to $2 \mathrm{~mm}$. To achieve compressive residual stress at deeper layer, several laser peening parameters must be changed. In this work, a comprehensive series of laser peening tests will be done in which process parameters, including pulse duration, pulse fluence, intensity, and number of pulses will be varied to achieve an optimum depth and intensity of compressive stress. Since the mechanical property and composition of canister welds might be changed as the welding process improves, it is fundamentally important to understand the predominant physics parameters and mechanisms that control the depth of compressive stress induced in Alloy 22 weld. Particular emphasis will be placed on achieving compressive stress at deeper depths than has currently been demonstrated.

Using the current baseline laser peening process setup and the $\mathrm{kW}$-class solid-state laser located in LLNL's Optical Science Laboratory, we will develop the motion hardware for performing the peening tests on Alloy 22 weld. The residual stress at deep layer will be measured using surface contour method recently developed by Professor Mike Hill at the University of California at Davis. Including experiment design, hardware fabrication and testing, and residual stress measurements, this task is estimated to be $\$ 500 \mathrm{~K}$.

\section{Task 2: Evaluation of a tamping material other than water}

Considering the volume of nuclear materials in a canister, it would be desirable to have a peening shock tamper other than water. A number of high dielectric strength, high mass liquids are potential candidates. One such example is fluorinert, which has better 
shock impedance and higher ionization potential than water. We propose to evaluate their performance in the laser peening process on Alloy-22 with particular emphasis on achieving compressive stress at deeper depths and reducing operation cost in hot cell environment. This task is estimated to be $\$ 100 \mathrm{~K}$.

\section{Task 3: Design and test optical transport system for remote peening of canister lids}

The laser peening system needs to be able to treat a remotely located canister in approximately 4 hours. The basic LLNL laser technology can achieve this goal, but we need to engineer a complete system for remote processing. In this task, options for laser system configuration, beam delivery, and peening processing will be evaluated. In particular, the design will include a concept for applying (and probably removing) the absorption/insulation layer as well as for applying and removing the tamping layer. It will also include a concept for rotating the beam around the circumference of the canister, tracking the weld. A conceptual design and demonstration of a prototype optical transport system will be generated. The estimated cost for this effort is $\$ 400 \mathrm{~K}$.

In the Second Phase, with laser peening established as the preferred solution to the SCC problem, we will improve the design of the current laser system and build a prototype system for full treatment of YMP's 6-ft-diameter canisters. As the laser peening technology progresses and the specifics of the commercially viable systems are determined, we will work jointly with U.S. industry to transfer the LLNL technology required to bring about the successful commercialization of the necessary laser system for YMP. We will also develop and demonstrate efficiency of laser annealing using highenergy laser beams to remove (or repair) residual weld stress not completely neutralized by the induction annealing process. The cost of this effort (Tasks $4 \& 5$ ) will be determined as the Phase One studies are complete.

\section{Task 4: Laser technology improvement to support production work}

The laser system used for production processing of canisters needs to be highly reliable and should require low maintenance. The prototype laser that exists at LLNL and the subsequent systems of its design that were built by LLNL to service DOD programs have moved the technology toward fully meeting production peening requirements. However, there are a few key areas where additional development would provide for higher-rate processing, lower maintenance, and, importantly, for achieving compressive stress at deeper layers in welds. In particular, technology has been designed that would allow for approximately a 10-times lifetime increase in the flashlamps. This 
would reduce maintenance intervals and lower operating costs. However, achieving this lifetime improvement requires demonstration of simmering of high-pressure lamp. We would build and activate this new circuitry and demonstrate a lifetime improvement. Another important addition to system performance would be a doubling of the laser repetition rate, pulse energy, and thus its average power. LLNL, in conjunction with Schott Glass Co. of Duryea, Pennsylvania, has developed a higher performance glass for the laser gain media but has not had the support to test its performance. We propose to test the performance of this glass so as to double the laser system throughput rate capability. Particular emphasis will be placed on optimizing the current laser peening system for producing compressive stress at deep layer in welds.

\section{Task 5: High-energy laser beams to eliminate defects and remove residual stress not neutralized by the induction annealing process}

Currently, the outer lid of waste package canisters will be TIG (tungsten inert gas) welded and followed by localized induction annealing (LIA) process. It is known that improper induction annealing process could overheat the closure weld, thereby producing undesirable intermetallic precipitates. These precipitates may cause the waste package to become brittle, and have lower corrosion resistance. Since LIA can only be applied once, and failure will result in fuel-assembly removals and discarded canisters, the ability to repair these valuable welds will reduce cost.

We propose to use highly localized laser beam to repair or remove defects and residual stress not completely neutralized in the LIA treatment. In this work, a comprehensive series of laser annealing experiments will be done in which process parameters, including pulse duration, pulse fluence, intensity, and number of pulses will be varied to achieve localized annealing and residual tensile stress removal in welds. Several non-destructive stress monitoring techniques (using surface acoustic wave or eddy currents, etc.) will be evaluated and developed to measure the thickness of subsurface compressive and tensile stress layers and to certify stress mitigation process. Using LLNL's $\mathrm{kW}$-class solid-state heat-capacity laser, we will perform material interaction experiments on Alloy 22 metal and welds. We will demonstrate efficiency of laser annealing to remove or repair residual weld stress and eliminate undesirable microstructures.

\section{Objective and Benefit to YMP}

Recent shock peening experiments on Alloy 22 welds using LLNL's high energy laser system have successfully demonstrated the feasibility of converting tensile stress in the 
weld and heat-affected areas into deep ( $2 \mathrm{~mm}$ depth) residual compressive stress. This stress-transformation method has proven to be very effective in preventing stress corrosion cracking of 316 stainless steel in aggressive $\mathrm{MgCl}_{2}$ solution and can potentially be used to retard any stress corrosion cracking in the canister welds and the heat-affected area around the welds.
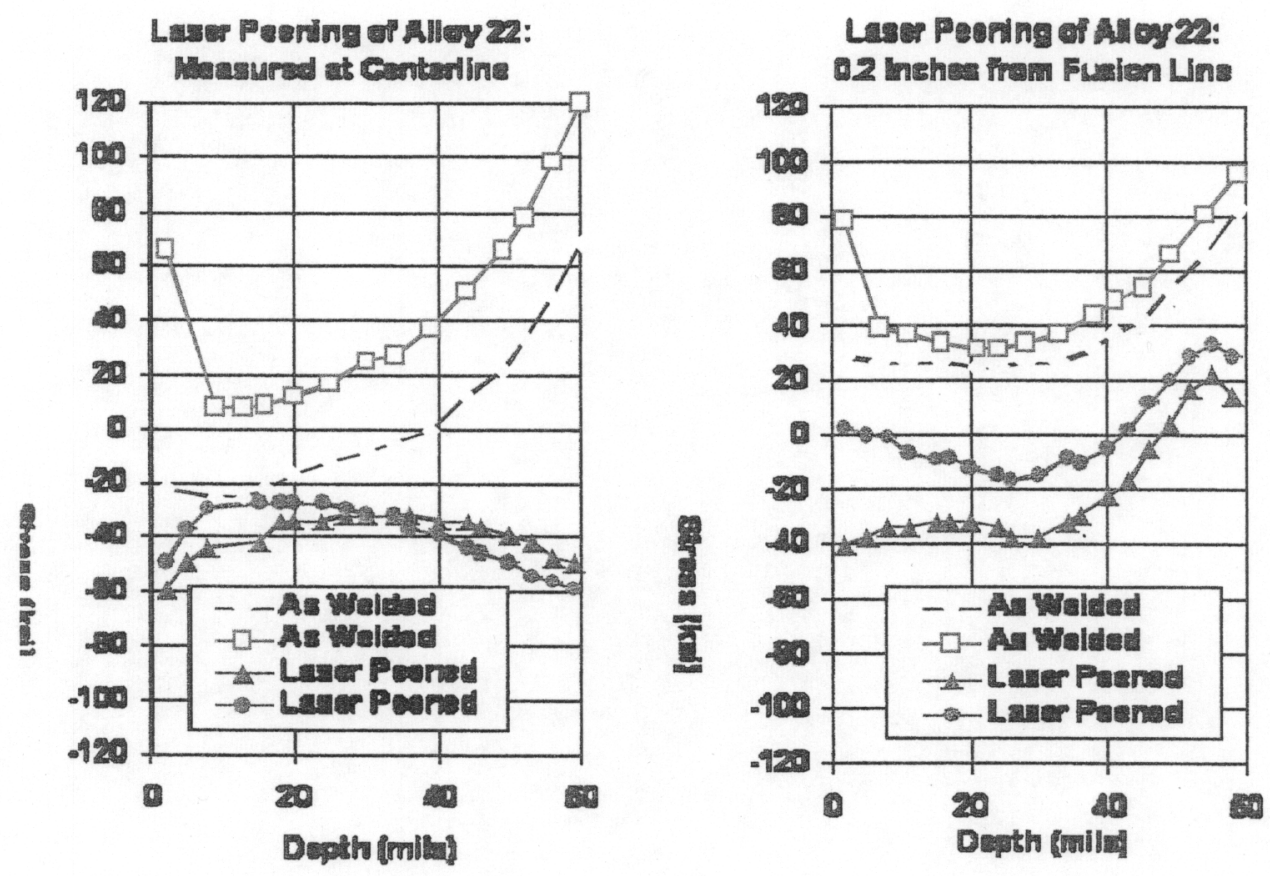

Figure 6. Application of laser peening to prototypical waste package weld, demonstrating the introduction of compressive stress into the outer surface. SCC in Alloy 22 welds is thereby prevented.

The objective of this work is to further optimize the laser peening process to achieve residual compressive stress at even greater depths $(>5 \mathrm{~mm})$. We will perform a parametric study on the depth of laser-induced compressive stresses in welds under various processing conditions (of laser pulse duration, fluence, intensity, pulse number, tamping materials, etc.). We will optimize process equipment design for hot cell operation. If successful YMP can apply the laser peening technology to reduce residual tensile stresses in welds for both inner and outer lids, or eliminate one of the lids completely. This can significantly reduce the overall cost of waste package production. 
Previous performance assessment calculations for the Alloy 22 waste package have shown that the application of stress mitigation can be an effective means of prolonging container life:

1. Threshold Stress Assumed + Laser Peening: First Failure $>10,000$ years

2. Zero Threshold Stress Assumed + Laser Peening: First Failure $~ 6,500$ years

3. Zero Threshold Stress Assumed + No Peening: First Failure $\sim$ several hundred years

The current plan is to fabricate the waste package containers with two closure lids. Inner lids will be TIG (tungsten inert gas) welded, followed by (LSP) laser shock peening. Outer lid will be TIG welded, followed by (LIA) localized induction annealing. In the case of the Alloy 22 waste package, improper LIA could overheat the closure weld, thereby producing undesirable intermetallic precipitates. These precipitates may cause the waste package to become brittle and to become lower corrosion resistance. In the case of amorphous alloys, LIA could also cause de-vitrification. It is known that LIA can only be applied once, and failures will result in fuel-assembly removals and discarded containers. Thus, the ability to repair these valuable welds will significantly increase the yield of usable canisters and hence reduce cost of canister production.

Laser peening process can also be used to eliminate tensile stresses in outer closure weld, thus eliminating the need for localized induction annealing (LIA). It has been demonstrated that laser peening can be used for the elimination of tensile surface stresses in crystalline alloys that can lead to SCC and corrosion fatigue. Toshiba has recently applied a similar laser peening technology to the stress relief of BWR pressure vessels (underneath water).

The replacement of LIA with laser peening will enable fabricators to avoid inadvertent overheating of the outer closure weld, and the possible precipitation of undesirable intermetallic phases in Alloy 22 waste packages, and the de-vitrification of advanced waste packages made from amorphous alloys. Furthermore, the laser peening process can be done repeatedly to produce compressive layers of desired depth and to reprocess localized weld repairs. In this work, the use of localized laser annealing with high-power lasers as an alternative to LIA will also be evaluated.

The ultimate goal of this work is to further advance the design of the laser peening and annealing systems for the Yucca Mountain Program (YMP) for producing deep 
(>5 mm) compressive stress in the closure welds, so that the waste package can be produced at low cost and stored for long time (10,000 years) without leakage. Upon completing the testing and engineering phases, we will transfer the laser peening and annealing technologies to U.S. industry and assist DOE to develop vendor for supply production units to be installed in the YMP repository.

If successful, the laser peening and annealing processes could be integrated into a single workstation, thereby simplifying operations, while eliminating the need for waste package movement inside hot cell. Replacement of LIA (localized induction annealing) with laser peening would enable the costly "extra skirt material" to be eliminated, as well as the extra inner lid $(\$ 17,000$ per container $x 12,000$ containers $=$ savings of $\sim \$ 200$ million). The possibility of localized weld repairs using laser annealing will reduce the number of waste packages rejected due to unacceptable closure welds, and the associated costs (waste package rejections could be $\sim 3 \%$ in high-yield closure process). Localized weld repair would also avoid the rejection of waste packages with flaws. The savings could be $\sim \$ 180 \mathrm{M}(12,000$ containers $\mathrm{x} \$ 500,000$ per container $\times 3 \%)$. 


\section{Dr. Lloyd A. Hackel}

Residence

1072 Sherry Way

Livermore, CA 94550

$925-443-6149$
Married

Excellent health

DOE Q Clearance

Born 10/14/49

\section{Education}

Sc.D.- September 1974, Instrumentation (Applied Physics) Massachusetts Institute of Technology, Cambridge MA Thesis: "High-Resolution Measurements on Iodine Using LaserMolecular Beam Techniques" Prof. S. Ezekiel, Advisor
M.S.- January 1973, Aeronautics and Astronautics
Massachusetts Institute of Technology, Cambridge MA
Thesis: "Molecular Beam Techniques for High Resolution
Spectroscopy" Prof. S. Ezekiel, Advisor

B.S. January 1971, Applied Mathematics and Engineering Physics University of Wisconsin, Madison WI

\section{Professional Accomplishments}

Most recently have been the Program Leader for Laser Science and Technology at the Lawrence Livermore National Laboratory. In this job I report directly to the Associate Director of the Laboratory a $\$ 1.3 \mathrm{~B}$ per year research and development center. I develop, sell and manage research and development programs that total approximately $\$ 50 \mathrm{M}$ per year. My staff includes over 150 scientists, engineers and technicians. The job includes all aspects of technical, business and personnel management including program definition and development, interaction with sponsors and customers, recruiting, business accounting and program execution.

Personally led development and deployment through technology transfer of a commercial laser peening system that was brought into service to fix a severe fatigue cracking problem in jet 
engine fan blades for Boeing 777 jets. This development, transfer and deployment has been extremely successful with over 30 engines fixed in the first 4 months of operation. Through this effort the laser peening technology has been established as a highly credible industrial process that will have enormous impact on component lifetimes for a broad range of systems.

In my previous job as Associate Program Leader for Laser Science and Technology, I built and managed a program activity within a National Laboratory environment that was focused on developing advanced laser and optical system technology for commercial and military applications. Work involved state-of-theart high average power and high average brightness solid state laser systems powered by both flashlamp and diode laser pumping. Have developed and demonstrated technology leading phase conjugation techniques for high beam quality. Developed systems have been integrated into important commercial and military applications winning three prestigious R\&D 100 awards in 1995, 1998 and 2001.

Managed a systems engineering analysis group at Lockheed Missiles and Space Company. Work involved the development of six major experiments in the Starlab Program, an SDIO funded pointing and tracking experiment intended to fly on the Space Shuttle. Developed all aspects of the experiments including design, development testing and integrated systems testing. Worked with the Air Force Space Division and NASA to implement the experiments in the Shuttle Mission.

Managed a team of 150 scientists, engineers and technicians in the development and operation of a half scale and then a full plant scale uranium separator system for the commercial application of Laser Isotope Separation. Specific emphasis on cost effective development of high rate, efficient metal vaporization, photoion extraction in a high temperature thermally balanced system, collection and transport of liquid metal and development of graphite materials and coatings, and refractory metal alloys to operate in a high temperature corrosive environment. Led the uranium separator facilities through the very important Demo 85 and Demo 87 enrichment campaigns.

Technical leader and manager of the development of a multigun, multi-megawatt electron beam vaporizer for use in the 
uranium separation program. Work included the design, testing and improvement of crucibles, electron guns, power conditioning equipment and metal feed and casting equipment. Developed a cw dye laser absorption technique using Doppler velocimetry and made measurements for the program of important atomic vapor parameters including single and multi-gun vapor distribution, flow velocity and Mach numbers, internal atomic temperature and vaporelectron and vapor-sputtered vapor interactions.

Lab leader in the development of the multi-step photo ionization process for the uranium isotope separation program. Work included extensive spectroscopic surveys of potential two and three step processes, measurement of isotope shifts, hyperfine structure and photo-absorption cross-sections on multiple levels up through the ionization limit. Defined the specific photo ionization process presently in use in the program and wrote patent disclosure details. Measured other important process parameters including charge exchange cross-section and $\mathrm{cw}$ and pulsed laser propagation in resonant and near-resonant media.

Developed state-of-the-art laser frequency stabilization using molecular beam references. Short term stability of 1 part in $10^{8}$ and long term stability of several parts in $10^{14}$ were demonstrated. Capability was applied to high resolution spectroscopy to measure an electron coupled nuclear spin-spin interaction in $I_{2}$.

Currently prepare numerous yearly publications and invited and contributed presentations on all areas worked. Four classified patent applications on isotope separation are on file. Six patents have been awarded on high average power solid state lasers and their applications and an additional four applications are on file.

\section{Work Experience:}

1999 - Present Program Leader for Laser Science and Technology, Managed a $\$ 50 \mathrm{M}$ per year program encompassing all major laser science development at the Laboratory. Team includes approximately 150 scientists, engineers, technicians and support personnel. Reports directly to Laboratory Associate Director. Major programs include $\$ 10 \mathrm{M}$ per year effort in laser driven fusion, $\$ 8 \mathrm{M}$ per year effort to develop an advanced laser system for tactical 
missile defense, $\$ 5 \mathrm{M}$ per year program in very short pulse lasers and the commercial development of laser peening.

1989 - 1999 Associate Program Leader for Commercial Laser Systems, Inertial Confinement Fusion Program, Laser Science and Technology since 94 and group leader since 89. Lead a group of 10 scientists and engineers in the development of advanced laser and optical systems for military and commercial applications. Identify concepts, define programs, secure outside funding for multi-million dollar efforts. Directed the building and delivery of high quality hardware. Two systems placed in the field last year have been awarded R\&D 100 awards for 1995.

1987 - 1989 Group Leader for Systems Engineering Analysis, Starlab Program, Astronautics Division, Lockheed Missiles and Space Company. Starlab was an SDIO sponsored program intended to fly a payload aboard the Space Shuttle to test target acquisition and tracking and the accurate pointing of lasers from a space platform. Group leader responsibility included the experiment design, hardware development testing, system test requirement specification, experiment error budget analysis and the analysis of test data.

1985 - 1987 Section Leader of both the Separator Operations and Technology Sections of the Atomic Vapor Laser Isotope Separation (AVLIS) Program at the Lawrence Livermore National Laboratory (LLNL). Responsible for program planning and implementation with a budget of about $\$ 25 \mathrm{M}$ per year and a staff of 150 scientists, engineers and technicians. The major effort in the operations section was the experiment planning and operation for technology development and enrichment demonstrations in a half scale facility and additionally, activation and reliable operation of a full scale separator demonstration facility. The Technology Section included groups which focused on specific aspects of the program technology including plasma physics, materials science, mechanical and thermal engineering process performance and instrumentation and control.

1981-1985 Separator Operations and Experiments Group Leader within the AVLIS Program at LLNL. Directed staff and operations of a half scale separator facility to vaporize and enrich uranium in large quantities. Activated and operated the facility including directing research and development on a $\mathrm{cw}$ dye laser technique for 
measuring three dimensional vapor density distribution, vapor electronic temperature, vapor flow velocity and Mach numbers and interactions between sputtered atoms and the streaming vapor.

1976 -1981 Physicist - Process Development Laboratory within the AVLIS Program at LLNL. Responsible for experiments to explore, define and measure parameters important to the multistep photo ionization process. Work included visible and infrared spectroscopy, use of high resolution mass spectrometers and atomic beam vapor sources. Explored processes such as field ionization, collisional ionization and autoionization to define optimum methods for process. Developed techniques for precisely measuring isotope shifts and hyperfine structure.

$1974-1976$ Physicist - Research Laboratory of Electronics, Massachusetts Institute of Technology. Developed techniques for laser frequency stabilization for use in high resolution spectroscopy, ring laser gyro and laser interferometer work.

\section{Honors and awards}

Elected to Phi Beta Kappa Honor Society based on undergraduate work at University of Wisconsin, Madison WI.

National Defense Education Act Fellow 1971 - 1974 MIT.

Federal Laboratory Consortium 1992 Award for Excellence in Technology Transfer, May 1992

R\&D 100 Award for High Average Power Solid State Laser System June 1995

R\&D 100 Award for Rapid Thermal Processing System, June 1995. Provided advanced arc lamp reflector technology to Intevac Corp.

R\&D100 Award for High Power Laser Peening System - June 1998

R\&D 100 Award for Laser Peenmarking System - June 2001

Over 25 publications in the field of laser science and technology 
Dr. Hao-Lin Chen

904 Kelley Court

Lafayette, CA 94549

hlhchen@msn.com

\section{Education}

Ph.D. in Chemistry, Indiana University 1967

B.S. in Chemical Engineering, Tunghai University 1962

\section{Professional Experience}

1998 to Present, Deputy Program Leader, Laser Science and Technology (LS\&T) Program, Lawrence Livermore National Laboratory (LLNL)

Manage technical interfaces within the Laser Science and Technology Program which include high average power solid-state laser technology, short-pulse laser technology, material processing technology, high-power diode laser and defense related projects. Provide programmatic oversight and technical direction to research and development activities. Review research proposals, budgets and profile for business development.

1997 to 1998, Principal Investigator, UC Campus-Laboratory Collaboration Program, LLNL (Professional Research Leave at UC Berkeley's Optoelectronics Group)

Plan and manage UC President Office's Target of Opportunity Project, for the development of large-area high power 2D-VCSEL laser array for optical pumping and communication applications. Design, fabricate and test monolithic 2D-VCSEL laser arrays. Provide programmatic oversight for effective University-Laboratory collaboration.

\section{2 to 1997, Deputy Manager for Technology, AVLIS Program, LLNL}

Manage technical and programmatic activities associated with the development of lasers, e-beams and materials processing technologies for Uranium Enrichment and other industrial applications. Plan and manage technology development and commercialization activities to transfer Uranium Enrichment and Electron Beam Technologies to industries.

\section{Awards}

- Winner of the 1995 R\&D 100 Awards for Development of Sealed Tube Electron Beam Guns for Material Processing: Selected as one of the 100 most Technologically Significant New Products of the year.

- Winner of the 1997 Federal Laboratory Consortium Awards for Excellence in Technology Transfer.

- Winner of the 2001 R\&D 100 Awards for Development of Lasershot Marking System: Selected as one of the 100 most Technologically Significant New Products of the year. 


\section{Professional Skills}

From 1990 to Present, as Deputy Program Manager at the National Laboratory, I am responsible for establishing strategic direction and plans for laser and electro-optics projects to develop and transfer advanced laser and material processing technologies to industry.

\section{Honors and Publications}

I have published 60 original papers and patents in the areas of lasers, laser kinetics, laser chemistry, molecular energy transfer, electron beam, gaseous electronics, and chemical processing of materials.

\section{Technical Book Publications}

Laser Spectroscopy and Its Applications, Chapter 4, "Applications of Laser Absorption Spectroscopy," Marcel Dekker, Inc., New York and Basel (1987).

\section{Most Recent Patent and Publications related to the proposed work}

1. "Rigid Thin Windows For Vacuum Applications, "US Patent for Electron Window Construction, Patent Number: 6002202, Date of Patent: Dec.14, 1999.

2. "Chemical and Materials Processing using Industrial Scale Visible Lasers," XX International Quantum Electronics Conference, Sydney, Australia, July (1996).

3. "Performance Measurements of Sealed-Tube Electron Beam Windows," RadTech Conference North America, April (1996), RadTech Conference Asia, Tokyo, Japan, November (1997).

4. "Monolithic 2D-VCSEL Array with $>2 \mathrm{~W}$ output Power " 16 th International Semiconductor Laser Conference (ISLC'98), Nara, Japan, October (1998).

5. "Collimated Diode Laser Beams from a Large-Area VCSEL-Array Using Microlens Array," IEEE Photonic Technology Letters (1999), Vol.11, No.5, Pg. 506.

6. "Monolithic 2D-VCSEL Array with $>2 \mathrm{~W} \mathrm{CW}$ and $>5 \mathrm{~W}$ Pulses Output Power," Electronics Letters (1999), Vol.34, No.22, Pgs 2132.

7. "Laser Peening Reduces Stress-Induced Corrosion and Cracking of Welds Laser Applications in the Department of Defense, State College, Pa. September (2000). 
FRANK M.G. WONG

Current Address:

4435 First St., \#411

Livermore, CA 94551

\section{Professional Interest:}

International materials research and development or manufacturing with management responsibility.

\section{Education:}

MASSACHUSETTS INSTITUTE OF TECHNOLOGY

Doctor of Philosophy in Nuclear Engineering, June 1990

Cambridge, MA

Thesis: "Fatigue, Fracture, and Life Prediction Criteria for Composite Materials in Magnets" (Advisor: R.G. Ballinger) Minor in continuum electromechanics. Areas of Concentration: fracture mechanics, computeraided testing, and plasma physics

MASSACHUSETTS INSTITUTE OF TECHNOLOGY

Master of Science and Bachelor of Science in Nuclear Engineering, June 1984

Cambridge, MA

Thesis: "Stresses and Flexibilities for Pressure Vessel Attachments" (Advisor: J.E. Meyer). Performed at Stone \& Webster Engineering Corporation as part of the M.I.T. Engineering Internship Program.

Skills:

Foreign Language: Fluent Japanese (speaking/reading/writing), worked in Japan Nov. 1990 - May 1999 Computer Languages \& Operating Systems: FORTRAN, BASIC, UNIX, Linux

Finite Element Method (FEM) Packages: ANSYS, SUPERTAB, invited instructor by ANSYS Inc. to conduct ANSYS training classes in Tokyo, Japan.

Mentoring: On the ITER Project (see below), trained and mentored several analysts in Russia and Japan in non-linear finite element analyses.

Licenses: Engineer in Training, Commonwealth of Massachusetts.

\section{Experience:}

YUCCA MOUNTAIN SITE CHARACTERIZATION OFFICE MANAGEMENT AND TECHNICAL SERVICES (MTS) TEAM, STONE \& WEBSTER, INC.

June 1999 to Present

Las Vegas, NV

Senior Engineering Specialist. Provide the Office of Civilian Radioactive Waste Management, US Department of Energy (DOE), with managerial and technical oversight of the Waste Package Materials and Waste Form Degradation testing, modeling, and analysis activities, and also Waste Package Fabrication activities, including welding and materials processing. These activities have had a combined value ranging from 25 to 35 million dollars per year. Responsibilities include identification, documentation, monitoring and resolution of significant waste package materials and waste form related project issues. Perform technical and programmatic reviews of major technical documents for project acceptance and public release. Examples of technical areas include: physical metallurgy, long-term degradation mechanisms, stress corrosion cracking, fabrication metaliurgy, spent fuel and waste glass dissolution, radionuclide solubility limits, and colloid phenomena. Assist the DOE in reviewing the annual updates of the long-range plan, integrated planning schedules, and scopes of work and schedules of waste package materials and waste form testing and performance modeling activities. Assist and review technical and management presentations in support of the Yucca Mountain Site Characterization Office (YMSCO) to DOE-HQ, the regulators, the Nuclear Waste Technical Review Board (NWTRB) and other interested parties. Strategize with the DOE in providing expertise to assure cost-effective performance for the Yucca Mountain Project contractor.

Other responsibilities include: technical specialist for many performance-based QA audits, technical monitor and reviewer of waste package materials and waste form tasks of the University Cooperative Agreement, technical interface for the International Waste Package Materials Performance Peer Review, international tour escort for the facilities at Yucca Mountain (especially for visitors from Japan and Asia).

INTERNATIONAL THERMONUCLEAR EXPERIMENTAL REACTOR (ITER), ENGINEERING DESIGN ACTIVITIES (EDA), JOINT CENTRAL TEAM December 1992 to May 1999

Naka, JAPAN 
Member of Superconducting Coils \& Structures Division. Seconded to ITER by Stone \& Webster Engineering Corporation. Responsibilities include international management and coordination of several ITER Design and R\&D tasks, structural analyses of the magnet system (including non-linear behavior), and metallic materials engineering. Coordinated and reviewed a materials characterization program involving all ITER Home Teams (US, Japan, Europe, and Russia) which were each valued between 0.6 and 1.2 million dollars per ITER Home Team. Results include:

- Full characterization of the cryogenic mechanical behavior of conductor conduit and structural materials for superconducting magnets (often using production material from the Model Coil programs), including Incoloy 908, nitrogen-strengthened austenitic stainiess steels, aged austenitic stainless steels. Welds of these materials were also characterized. (All Home Teams)

- Development and demonstration of manufacturing processes to control stress accelerated grain boundary oxidation (SAGBO) in Incoloy 908, a conduit material used in $\mathrm{Nb}_{3} \mathrm{Sn}$ cable-in-conduit superconductor. $6 \mathrm{~km}$ of superconductor for the Model Coil were successfully heat treated and showed that SAGBO can be avoided on an industrial scale in superconducting magnet fabrication. (US and Japan)

- Qualification of stainless steel heavy-section forgings (up to $500 \mathrm{~mm}$ thick) and weldments (up to 250 $\mathrm{mm}$ thick) for operation at cryogenic temperatures. Large mock-ups of coil sections (up to 70 tonnes) which included up to $200 \mathrm{~mm}$ thick forgings, welds, and castings were also fabricated and qualified. (Japan and Europe)

Managed and reviewed structural analyses for magnets also involving all ITER Home Teams at a level of about 2 to 4 professional person years (PPY or FTE) per annum per Home Team. Also responsible for writing and coordinating the magnet structural analyses, materials database, and structural design criteria sections of the ITER Design Documents.

\section{MECHANICAL ENGINEERING RESEARCH LABORATORY, HITACHI LTD. Hitachi City, JAPAN}

November 1990 to November 1992

Visiting Researcher. Formulated, managed, and performed research to assess Carbon Fiber / Carbon Matrix $(\mathrm{C} / \mathrm{C})$ composites as suitable tokamak armor material through mechanical behavior and thermal shock experiments and analyses. Participated in collaborative research projects with the Fusion Design Section of the Hitachi Works, Hitachi Energy Research Laboratory, Hitachi Research Laboratory, and the Japan Atomic Energy Research Institute which included ITER-related divertor plate module simulation testing, vacuum vessel manufacturing design, and future upgrades of the JT-60U tokamak. Also participated in the structural and mechanical reliability assessment of the helical coils of the Large Helical Device (LHD) and conducted experiments for the research activities of the Japanese Fusion Structural Design (FSD) committee.

MIT PLASMA FUSION CENTER

January 1984 to October 1990

Cambridge, MA

Research Assistant. Doctoral thesis investigated the fatigue crack growth behavior and developed a life prediction model for an explosively-bonded copper/Inconel 718/copper laminate composite, a candidate material developed for the toroidal field magnets of the Alcator C-MOD tokamak, which has been constructed at MIT. Also worked on other aspects of Alcator C-MOD design and materials R\&D, including the toroidal field (TF) coil sliding joint, Ohmic transformer, and tokamak containment and support structures. Assisted in many of the construction activities for this tokamak.

June - October 1990: Project Coordinator for the Alcator C-MOD research group. Responsible for generating monthly internal engineering/construction budget, coordinating monthly technical progress reports to the U.S. Department of Energy, and coordinating and replying to daily/weekly technical correspondence between C-MOD project and large contractors. Performed technical photography and materials research/testing as needed.

STONE \& WEBSTER ENGINEERING CORPORATION June 1981 to December 1986

Boston, MA

Engineering Intern. Master's thesis extended and advanced Bijlaard's technique of determining stresses at nozzle-shell junctions through double-sum Fourier analysis. The thesis resulted in a computer package that determined stresses and deflections through a closed-form solution. After completion of the thesis, this package was enhanced and transformed into a qualified engineering production tool.

Other projects included developing and upgrading interactive color graphic software for the ComputerAided Design Engineering of Piping and Supports project, performing a dynamic and static seismic analysis to qualify safety equipment for a nuclear power plant, and performing finite-element analyses on various trunnion designs for the Pipe Stress and Supports Group. 
Frank M.G. Wong - 3

THE CHARLES STARK DRAPER LABORATORY, INC.

November 1979 to May 1981

Cambridge, MA

Worked part-time as a computer programmer to develop an interactive computer graphics package that was used to produce schematic diagrams, flowcharts, and technical drawings.

SAM O. HIROTA, INC. (Civil Engineering, Surveying, and Computer Graphics) Winter vacation (1980-81)

Honolulu, $\mathrm{HI}$

Worked as a computer programmer to develop and modify detailed road and utility profile plots which were applied to elevation analyses.

MEDIA FIVE, LTD.

Summer and winter vacations $1977-1980$

Honolulu, $\mathrm{HI}$

Multi-media specialist and graphics artist. Created fully-automated muiti-media presentations, using multi-image programming equipment, for various commercial architecture applications.

\section{Background and Interests:}

Raised in Honolulu, Hawaii. Graduated from Punahou School with honors, June 1979. 1977 Japanese Language Award. Wind Ensemble and Concert Orchestra. Free-lance Photographer: weddings, architectural and technical projects, prints from color slides (Cibachrome process), and darkroom work. Interests: piano, sailing, and snorkeling.

Citizenship: United States of America 
Frank M.G. Wong - 4

\section{Publications/Presentations:}

Wong, F.M.G. and Payer, J.H., Eds. Yucca Mountain Project Waste Package Materials Performance Peer Review: A Compilation of Special Topic Reports, monograph in press.

Wong, F.M.G., "Fabrication Processes and Metallurgy: Peer Review Sub-Panel Meeting with International Materials Experts," Wong, F.M.G. and Payer, J.H., Eds. Yucca Mountain Project Waste Package Materials Performance Peer Review: A Compilation of Special Topic Reports in press.

Wong, F.M.G., Stockman, C., et al, "Overview of Waste Form Degradation Process Models for Performance Assessment," Proceedings of the International Symposium NUCEF 2001: Scientific Bases for Criticality Safety, Separation Process, and Waste Disposal (October 31 - November 2, 2001), Japan Atomic Energy Research Institute (JAERI), JAERI-Conf 2002-004, March 2002.

Wong, F.M.G., Stockman, C., Mertz, C., et al, "Colloids-Associated Concentrations Model and Experimental Studies for a Waste Form Degradation Process Model," Proceedings of the International Symposium NUCEF 2001: Scientific Bases for Criticality Safety, Separation Process, and Waste Disposal October 31 - November 2, 2001), Japan Atomic Energy Research Institute (JAERI), JAERI-Conf 2002004, March 2002.

Wong, F.M.G., "Strategies and Demonstration Activities for Stress Mitigation Techniques to Minimize the Potential of SCC in Closure Welds of Nuclear Waste Containers, presented at 2001 ICG-EAC, International Cooperative Group on Environmentally Assisted Cracking of Light Water Reactor Materials, Kyongju, South Korea, April 2001, Invited Presentation.

Wong, F.M.G, "Introduction to the Yucca Mountain Project and its Waste Package Materials Degradation Activities, presented at 2001 ICG-EAC, International Cooperative Group on Environmentally Assisted Cracking of Light Water Reactor Materials, Kyongju, South Korea; April 2001, Invited Presentation.

Wong, F.M.G., Mitchell, N.A., et al, "Characterization of Incoloy 908 and Avoidance of Stress Accelerated Grain Boundary Oxidation (SAGBO) During ITER Model Coil Fabrication," Proceedings of ANS 13th Topical Meeting on the Technology of Fusion Energy, Nashville, TN, USA, June 1998, Invited Paper.

Wong, F.M.G., Mitchell, N.A., "Selection of Tokamak Toroidal Field Coil Structural Materials," Advances in Cryogenic Engineering Materials, Vol. 44, Plenum Press, 1998.

Wong, F.M.G., Mitchell, N.A., et al, "Selection of Jacket Materials for $\mathrm{Nb}_{3} \mathrm{Sn}$ Superconductor," Proceedings of 19th Symposium on Fusion Technology (SOFT), Lisbon, Portugal, September 1996.

Wong, F.M.G., Mitchell, N.A., et al, "Residual Stresses in Superconducting Jackets After Compaction," Proceedings of the 16 ICEC/ICMC, Kitakyushu, Japan, May 1996.

Wong, F.M.G., Sborchia, C., Thomer, R., Malkov, A., and Titus, P., "Structural Design of the Superconducting Toroidal Field Coils for ITER," Proceedings of 18th Symposium on Fusion Technology (SOFT), Karisruhe, Germany, August 1994.

Wong, F.M.G., "Compliance Analysis and Geometry Effects on R-Curve Behavior of a Carbon-Fiber Reinforced Composite," Research Report, Mechanical Engineering Research Laboratory, Hitachi Ltd. November 1992.

Wong, F.M.G., "A Simple Fiber Bridging Model for R-Curve Analyses of a Carbon-Fiber Reinforced Composite," Research Report, Mechanical Engineering Research Laboratory, Hitachi Ltd., September 1992.

Wong, F.M.G. and Sakurai, S., "A Comparison of Fracture Toughness For Carbon-Based Fusion Armor Materials Using An R-Curve Approach," JSME Material Mechanics Conference, September 1992, Sapporo, Japan.

Wong, F.M.G. and Sakurai, S., "A Comparative Fracture Toughness Evaluation of Carbon-Based Armor Materials for Fusion Applications," Fusion Technology, in press.

Wong, F.M.G., Fatigue, Fracture, and Life Prediction Criteria for Composite Materials in Magnets, MIT Plasma Fusion Center Report, PFC/RR-90-10, DOE/ET-51013-285, June 1990.

Wong, F.M.G., "Current Status of MIT's New Tokamak Experiment," Guest Speaker, IEEE Hawaii Chapter Meeting, January 1990, Honolulu, HI. 
Frank M.G. Wong - 5

Wong, F.M.G., and Ballinger, R.G., "Crack Growth Behavior in an Explosively-Bonded Laminate Conductor," Thirty-First Annual Meeting, Division of Plasma Physics, American Physical Society, November 1989, Anaheim, CA.

Wong, F.M.G., and Ballinger, R.G., "Fatigue Studies on the Alcator C-MOD Explosively-Bonded Laminate," Thirtieth Annual Meeting, Division of Plasma Physics, American Physical Society, October 1988, Hollywood, FL.

Wong, F.M.G., Craft, W.L., and East, G.H., "Stresses and Deflections in Cylindrical Pressure Vessels Due to Torsional Loads," 1985 Pressure Vessel and Piping Conference and Exhibition, June 1985, New Orleans, LA.

Wong, F.M.G., Craft, W.L., and East, G.H., "Stresses and Displacements in Vessels Due to Loads Imposed by Single and Multiple Attachments," ASME Journal of Pressure Vessel Technology February 1985.

Wong, F.M.G., Craft, W.L., and East, G.H., "Stresses and Displacements in Vessels Due to Loads Imposed by Single and Multiple Attachments," 1984 Pressure Vessel and Piping Conference and Exhibition, June 1984, San Antonio, TX. 
Assistant Professor

\section{Michael R. Hill}

Mechanical and Aeronautical Engineering Department

2014 Bainer Hall

University of California

One Shields Avenue

Davis, CA 95616-5294

(530)754-6178 (w)

(530)752-4158 (fax)

mrhill@ucdavis.edu

\section{Research Interests and Expertise}

$O$ Fatigue and fracture: analysis and testing

0 Residual stress measurement

$\checkmark$ Surface treatments for metals

$\checkmark$ Elastic plastic finite element simulation

$\checkmark$ Experimental mechanics

$\checkmark$ Mechanical design

\section{Recent Research Activities}

The following projects combine residual stress measurement, non-linear finite element analysis, experimental material characterization, and failure prediction:

- Laser peening: optimal fatigue life improvement, laser peen forming, process variations

- Fracture toughness measurement in welded materials

- Correction of fracture toughness data for residual stress effects

- Modeling of fatigue and ductile tearing in residual stress bearing high-strength aluminum

The following projects are focused on the measurement of residual stress:

- Measurement of residual stress in metallic-ceramic functionally-graded materials

- Improved error estimation for the compliance method of residual stress measurement

- Improved stress computation for the deep-hole method of residual stress measurement

\section{Courses Taught}

EME150A - Introduction to Mechanical Design

EME176 - Measurement Systems

MAE250A - Advanced Methods in Mechanical Design I

MAE250B - Advanced Methods in Mechanical Design II

MAE250C - Material Performance in Design

\section{Education}

Ph.D. in Mechanical Engineering, September 1996. STANFORD UNIVERSITY, Stanford, CA. Emphasis in material science, solid mechanics, and residual stress measurement. Advisors: Drew V. Nelson and Sheri Sheppard.

M.S. in Mechanical Engineering, May 1991. UNIVERSITY OF ARIZONA, Tucson, AZ. Emphasis in probabilistic design, mechanics, and structural dynamics.

B.S. in Mechanical Engineering, May 1989. UNIVERSITY OF ARIZONA, Tucson, AZ.

\section{Employment History}

Assistant Professor, University of California, Davis, CA.

Research Assistant, Stanford University. Residual stress measurement.

$9 / 96$ - Present

Consultant, Sverdrup, Ames Division. Prediction of ductile tearing in metals.

Consultant, Apple Computer. Characterization of LCD-panel failures.

\section{Professional Activities}

Member, American Society of Mechanical Engineers, Pressure Vessels and Piping Division, Materials and Fabrication Committee

Member, American Society for Testing and Materials, Committee E08 on Fatigue and Fracture, and Committee F08.10 on Bicycles

Member, ASM International (formerly American Society for Metals)

Participant, Creativity in Engincering Education Workshop, Stanford University, 1995 